Article

\title{
New Water-Soluble Carbamate Ester Derivatives of Resveratrol
}

\author{
Andrea Mattarei ${ }^{1}$, Massimo Carraro ${ }^{2}$, Michele Azzolini ${ }^{3}$, Cristina Paradisi ${ }^{1}$, Mario Zoratti ${ }^{3,4}$ \\ and Lucia Biasutto ${ }^{3,4, *}$
}

1 Department of Chemical Sciences, University of Padova, Via F. Marzolo 1, 35131 Padova, Italy; E-Mails: andrea.mattarei@unipd.it (A.M.); cristina.paradisi@unipd.it (C.P.)

2 Department of Chemistry and Pharmacy, University of Sassari, Viale Vienna 2, 07100 Sassari, Italy; E-Mail: mcarraro@uniss.it (M.C.)

3 Department of Biomedical Sciences, University of Padova, Viale G. Colombo 3, 35121 Padova, Italy; E-Mails: michele.azzolini@gmail.com (M.A.); zoratti@mail.bio.unipd.it (M.Z.)

4 CNR Neuroscience Institute, Viale G. Colombo 3, 35121 Padova, Italy

* Author to whom correspondence should be addressed; E-Mail: lucia.biasutto@cnr.it; Tel.: +39-049-8276-483; Fax: +39-049-8276-040.

External Editor: Arthur S. Polans

Received: 27 August 2014; in revised form: 22 September 2014 / Accepted: 24 September 2014 / Published: 1 October 2014

\begin{abstract}
Low bioavailability severely hinders exploitation of the biomedical potential of resveratrol. Extensive phase-II metabolism and poor water solubility contribute to lowering the concentrations of resveratrol in the bloodstream after oral administration. Prodrugs may provide a solution-protection of the phenolic functions hinders conjugative metabolism and can be exploited to modulate the physicochemical properties of the compound. We report here the synthesis and characterization of carbamate ester derivatives of resveratrol bearing on each nitrogen atom a methyl group and either a methoxy-poly(ethylene glycol)-350 (mPEG-350) or a butyl-glucosyl promoiety conferring high water solubility. Ex vivo absorption studies revealed that the butyl-glucosyl conjugate, unlike the mPEG-350 one, is able to permeate the intestinal wall. In vivo pharmacokinetics confirmed absorption after oral administration and showed that no hydrolysis of the carbamate groups takes place. Thus, sugar groups can be attached to resveratrol to obtain soluble derivatives maintaining to some degree the ability to permeate biomembranes, perhaps by facilitated or active transport.
\end{abstract}


Keywords: resveratrol; prodrugs; carbamate esters; solubility; poly(ethylene glycol); glucose

\section{Introduction}

Resveratrol has the potential to prevent, alleviate or slow the progression of a wide variety of illnesses, including cardiovascular disease, metabolic syndrome, cancer, ischemic injuries, cognitive decline, inflammatory ailments. It can enhance stress resistance and extend the lifespan of some model organisms. Studies dealing with the mechanisms underlying the bioactivity of resveratrol have been summarized in many reviews (e.g., [1-8]). Activation of the AMP-regulated kinase AMPK and of the NAD-dependent deacetylase Sirt-1, and the consequent effects on gene expression, are important features of the signaling network [9-12].

Bioavailability is fundamental for the full realization of the biomedical potential of nutraceuticals; many polyphenols have pharmacokinetic/pharmacodynamic and physicochemical properties that limit their chance of being developed into pharmaceutical products. The efficacy of orally administrated resveratrol depends on its absorption, metabolism, and tissue distribution. The distribution of resveratrol and its metabolites in organs has been investigated [13-15]. Only trace amounts (below $5 \mathrm{ng} / \mathrm{mL}$, i.e., $22 \mathrm{nM}$ ) of unchanged resveratrol could be detected in human plasma after a $25 \mathrm{mg}$ oral dose [16]. A recent study of the distribution of pterostilbene (3,5-O-dimethylresveratrol) and pterostilbene sulfate in the rat has however shown that blood or plasma concentrations cannot be automatically considered a reliable index of total body levels [17]. The dose escalation approach has been investigated, covering a total dose range of 25-5,000 $\mathrm{mg}$ [18] but even at the highest doses the concentrations of resveratrol in plasma (peak: $550 \mathrm{ng} / \mathrm{mL}$, i.e., $\sim 2.4 \mu \mathrm{M}$ ) seemed too low to provide a plausible explanation of effects. Indeed in enterocytes resveratrol is rapidly converted by conjugating enzymes to metabolites that are re-exported, largely to the intestinal lumen, by ABC transporters [19,20]. Liver sulfotransferases (SULTs) and glucuronosyltransferases (UGTs) then intervene on the molecules that have entered the circulation. Studies on in vivo bioavailability and metabolism of resveratrol indicate that glucuronides, sulfates and double-bond reduction products formed by gut microflora are major metabolites [13,18,21-23]. Marked differences in the relative relevance of these conjugative processes may be observed, depending on the species and also on factors such as gender or dosage (see, e.g., [24-26]). Most studies suggest sulfation to be the major modification in rodents, while glucuronidation appears more important in humans [17], but the significance of sulfation in humans may need reconsideration [14]. Metabolites themselves may have some degree of bioactivity (e.g., [27-34]) and the relative proportions of the two major sets of metabolites - sufates vs. glucuronides - may be a factor in determining overall bioactivity. While the contribution of these conjugates would be expected to depend on the specific cellular or molecular process being considered, in general their increased size, polarity and hydrophilicity may be seen as an obstacle for interaction with many enzymes.

Experimental data support the idea that sulfates and glucuronides of resveratrol may act as a sort of storage device, regenerating the aglycone through the action of sulfatases and glucuronidases [35-37]. Nonetheless, devising ways to increase levels and slow metabolic transformation of resveratrol after oral administration clearly is an important endeavor [38]. Many formulation-based approaches to 
overcome the solubility obstacle, improving stability and/or enhancing absorption and efficacy of resveratrol have been considered: inclusion into cyclodextrins [39,40], micro/nano emulsions [41-43], nano suspensions [44], micelles [45,46], nanostructured lipid carriers [47-49], liposomes [43,47,50], nanochannel delivery membrane systems [51], and various types of nanoparticulated carriers [48,52-61]. Another main strategy used to prevent drug metabolism and enhance bioavailability and effectiveness is based on the development of "prodrugs" [62,63]. In the case of resveratrol this would consist in protecting reactive sites (hydroxyl moieties) with removable groups (promoieties), thus opposing phase II metabolic processes. The prodrug approach is furthermore often used to introduce favorable physicochemical properties, in particular to modulate water solubility, via the promoieties. An ideal prodrug has both good absorption and bioconversion characteristics. The latter clearly depend on the type of chemical bond system used to link the promoiety to the "core" of the molecule.

Carbamate esters are one of the most popular types of prodrugs, used for example with duocarmycin [64], camptothecin [65], entacapone [66] and (-)-3-(3-hydroxyphenyl)-N-propylpiperidine [67]. We report here the synthesis and performance of $N, N$-disubstituted resveratrol carbamates. To improve solubility, butyl-glucosyl or methoxy-poly(ethylene glycol)-350 (mPEG-350; average molecular weight $350 \mathrm{Da}$ ) groups were introduced as promoieties (Scheme 1).

Scheme 1. Chemical structures of resveratrol $\mathbf{1}$ and carbamoyl derivatives $\mathbf{2}$ and $\mathbf{3}$.

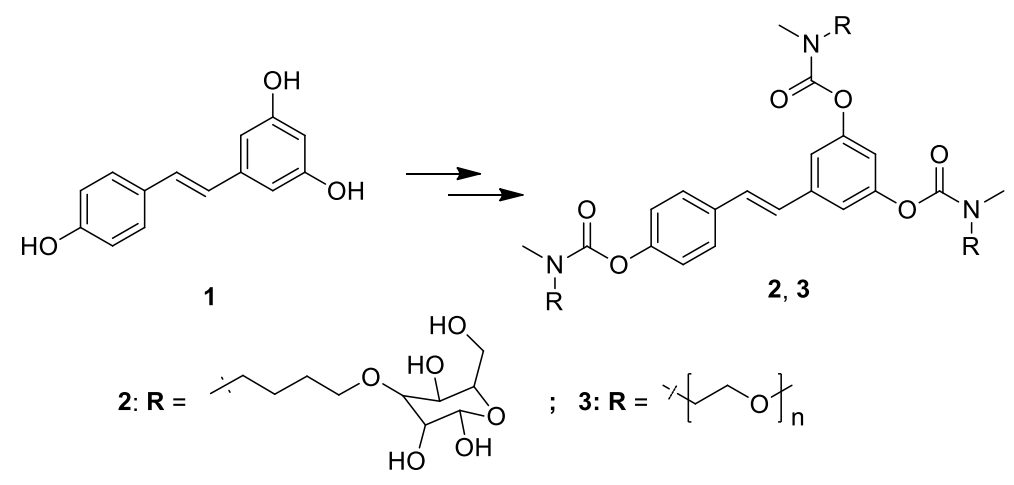

Many prodrugs designed to increase water solubility involve the addition of an ionizable promoiety to the parent molecule. Because charged molecules have great difficulty crossing biological membranes, one must balance increased water solubility against a potentially decreased permeability. Based on this consideration we chose non-ionizable solubilizing groups. Conversion of a compound into a more hydrophilic one is not necessarily going to help absorption either, since the energetic barrier opposing diffusion through the lipid core of biological membranes is expected to become more important. However both groups we used, glucose and mPEG-350, have features that may provide increased solubility without unduly compromising absorption. Increased water solubility constitutes an obvious advantage also for administration routes other than oral, such as intravenous injection or slow-release implanted capsules.

It may be possible, by incorporating glucose into the promoiety, to take advantage of the presence of glucose transporters in the absorbing epithelium. While flavonoid or resveratrol intestinal uptake may also occur by simple diffusion through the enterocyte membrane, studies have implicated intestinal transporters of the SGLT and GLUT families in the uptake of glycosylated derivatives $[68,69]$. 
Attachment of poly(ethylene glycol) (PEG) moieties to therapeutic compounds ("pegylation") may improve drug absorption and pharmacokinetics [70-74]. PEG is known to be non-toxic, non-antigenic and biocompatible and indeed the FDA has approved its use as a vehicle or base in foods, cosmetics and pharmaceuticals. In this work, mPEG-350 was chosen as a promoiety to modify resveratrol because it can increase both water and lipid solubility of a drug and we reasoned that the latter effect may facilitate the penetration of resveratrol through biological membranes.

\section{Results and Discussion}

\subsection{Synthesis}

Derivatives 2-3 (Scheme 1) were obtained through condensation of resveratrol (1) with the appropriate carbamoyl chloride. The synthesis of $\mathbf{2}$ is outlined in Scheme 2. The starting material for the glucosyl carbamate was commercially available 1,2:5,6-di- $O$-isopropylidene- $\alpha$-D-glucofuranose (4) which was allowed to react with an excess of 1-bromo-4-chlorobutane in the presence of sodium hydride to give $\mathbf{5}$ in fair yield through Williamson etherification. In the second step, compound $\mathbf{5}$ was treated with methylamine under microwave irradiation to obtain the secondary amine $\mathbf{6}$ in a short reaction time. This intermediate was allowed to react with triphosgene under mild conditions to give the carbamoyl chloride (7) which was used without further purification in the subsequent step. Compound 7 was added in slight excess to resveratrol (1) in pyridine and allowed to react at reflux to obtain the carbamate derivative $\mathbf{8}$ in good yield. The last step consisted in the removal of the acetonide protecting groups from the glucofuranosyl rings, freeing the hydroxyl functions necessary to enhance the solubility in water of the final product (2). The reaction was performed in trifluoroacetic acid:water, 9:1, at room temperature. Under these conditions the carbamate group is stable and the desired product was obtained in excellent yield.

Scheme 2. Synthesis of compound 2.

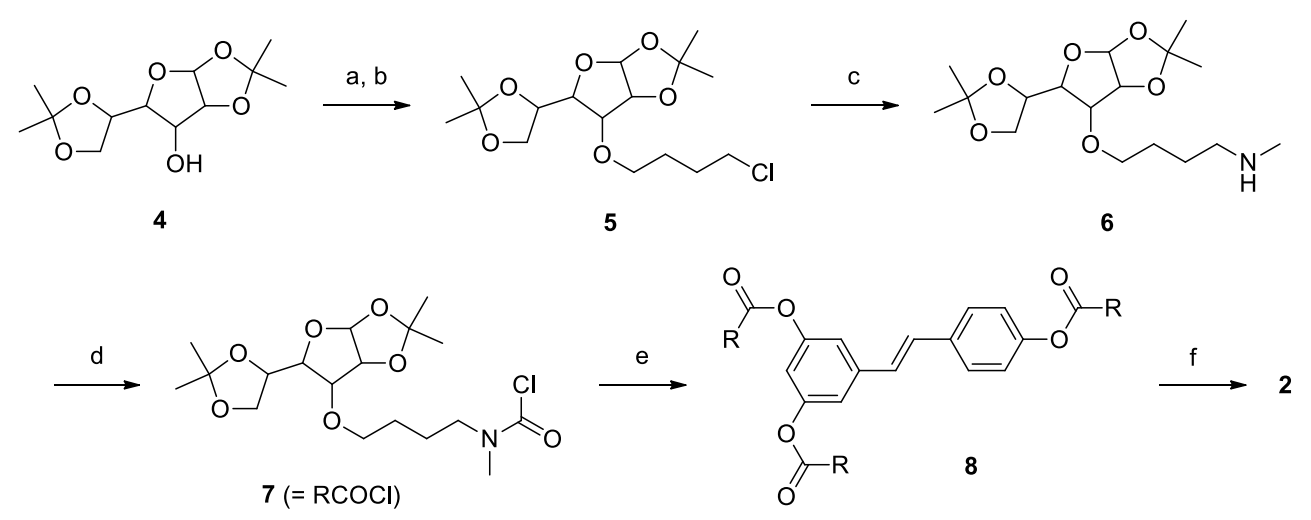

Reagents and conditions: (a) $\mathrm{NaH}$, DMF, r.t., 30 min; (b) $\mathrm{Br}\left(\mathrm{CH}_{2}\right)_{4} \mathrm{Cl}, 40{ }^{\circ} \mathrm{C}, 24 \mathrm{~h}$; (c) $\mathrm{CH}_{3} \mathrm{NH}_{2}$, EtOH, Microwave $150{ }^{\circ} \mathrm{C}, 30 \mathrm{~min}$; (d) triphosgene, pyridine, DCM, $0{ }^{\circ} \mathrm{C}$ to r.t., $45 \mathrm{~min}$; (e) DMAP, 1, pyridine, reflux, overnight; (f) trifluoroacetic acid : water 9:1, r.t., 1 h.

The synthesis of derivative 3 (Scheme 3 ) was more straightforward, since there was no need to introduce a spacer or for a deprotection step. The starting material was a simple and cheap methoxypoly(ethylene glycol) with an average molecular weight of $350 \mathrm{Da}(9)$, possessing one free hydroxyl 
group which was esterified with tosyl chloride to obtain compound $\mathbf{1 0}$. The tosylate group of $\mathbf{1 0}$ was easily displaced in the second step by methylamine under microwave irradiation giving the secondary amine $\mathbf{1 1}$ in nearly quantitative yield. Finally, amine $\mathbf{1 1}$ was treated with triphosgene to give the carbamoyl chloride 12, which in turn was allowed to react with resveratrol to afford the desired product 3.

Scheme 3. Synthesis of compound 3.

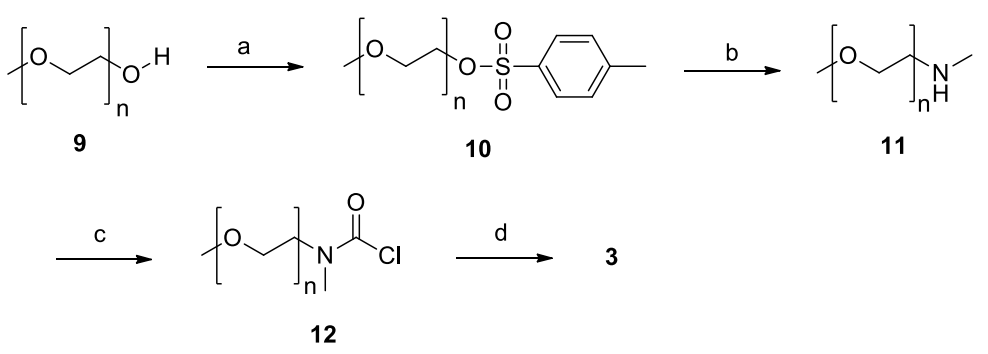

Reagents and conditions: (a) 1. $\mathrm{NaOH}, \mathrm{H}_{2} \mathrm{O} / \mathrm{THF}, 0{ }^{\circ} \mathrm{C}, 2$. TosCl, $5{ }^{\circ} \mathrm{C}, 2 \mathrm{~h}$; (b) $\mathrm{CH}_{3} \mathrm{NH}_{2}, \mathrm{EtOH}$, Microwave $150{ }^{\circ} \mathrm{C}, 30 \mathrm{~min}$; (c) triphosgene, pyridine, DCM, $0{ }^{\circ} \mathrm{C}$ to r.t., $45 \mathrm{~min}$; (d) DMAP, $\mathbf{1}$, pyridine, reflux, overnight.

\subsection{Solubility}

Both derivatives displayed good water solubility $(>50 \mathrm{mM})$. This represents a strong increase with respect to resveratrol, the reported solubility for which ranges from $\leq 1 \mu \mathrm{M}$ to $300 \mu \mathrm{M}$ [75-78]. As can be noticed, these data from the literature are very variable, probably because of the difficulty in determining accurate solubility data for compounds that can form colloids.

\subsection{Permeation across Rat Intestine}

We assayed transport of the derivatives across explanted rat jejunum segments using Ussing-type chambers. This system allows the study of transepithelial transport separately from other processes taking place in the intestinal lumen, in blood, or in the liver. In these experiments, the same amount of resveratrol or derivative was loaded on the apical side; both apical and basolateral chambers were then analyzed after $2.5 \mathrm{~h}$ (see Experimental Sections for details).

In agreement with our previous observations [78,79], resveratrol reached the basolateral compartment mainly $(\geq 90 \%)$ in the form of phase II metabolites (sulfate(s) and glucuronide(s)); basolateral species collectively accounted for $0.6 \%-1.5 \%$ of the amount placed initially in the apical side chamber. In the same experimental setup and conditions, a similar translocation $(1.7 \pm 0.7 \%)$ was observed for derivative 2 ; in this case, however, only the intact derivative was detected in the basolateral chamber; resveratrol and its metabolites were below the detection threshold, and no products deriving from partial deprotection of the hydroxyl groups (hydrolysis of one or two of the three carbamate groups) could be detected either. Somewhat to our surprise, no compounds with a stilbenoid structure could be detected in the basolateral chamber when derivative $\mathbf{3}$ was placed in the apical one. No further experiments were conducted with this compound.

Passage of the glucosyl-derivative 2 across the intestinal wall is remarkable, since it is too hydrophilic to undergo passive diffusion through cell membranes. A possible explanation may be the 
involvement of a facilitated or active transport mechanism, possibly mediated by glucose transporters. Dietary glucose crosses the apical membrane of the enterocyte by the $\mathrm{Na}^{+} /$glucose cotransporter (SGLT1) and exits across the basolateral membrane through the facilitative transporter GLUT2. Before a meal, the concentration of glucose in the lumen is very low. Any glucose is rapidly captured by SGLT1, which is ideal for this purpose, being a low-capacity, high-affinity transporter and the only transporter capable of moving glucose against a concentration gradient. GLUT2 is a high-capacity, low-affinity facilitative transporter that equilibrates glucose between plasma and enterocyte. We thus investigated the absorption of derivative 2 through excised rat jejunum in the presence of different concentrations and combinations of inhibitors of SGLT-1 (phlorizin) and GLUT-2 (phloretin and cythochalasin B). To minimize the possibility of competitive inhibition by medium glucose, we also decreased glucose concentration in the assay medium from $\sim 55$ to $1 \mathrm{mM}$, substituting it with mannitol, and/or increased the concentration of derivative 2 to levels close to that of glucose $(0.5 v s 1 \mathrm{mM})$.

After a meal, there is a high effective glucose concentration at the surface of the apical membrane. The initial glucose transport across the apical membrane results in rapid insertion of GLUT2 into the apical membrane from intracellular vesicles underlying the membrane. Apical GLUT2 is now the major pathway of absorption. Then, when the glucose concentration in the lumen falls, the whole signaling system is reversed so that GLUT2 is inactivated and traffics away from the apical membrane to restore the situation before a meal [80,81]. To determine if the administration of glucose could enhance the absorption of derivative 2, thus providing evidence for a role of GLUT2 in its transport, we performed transport experiments using the intestine from non-fasted rats, and from rats who had received glucose in their drinking water $(20 \mathrm{~g} / \mathrm{L})$ in the $24 \mathrm{~h}$ prior to the experiment.

The extents of translocation under the various conditions mentioned above turned out not to differ significantly one from the others. Dynamic trafficking of GLUT-2 [82] may contribute to the observed variability: its levels in ex vivo intestinal preparations can be greatly reduced compared to the in vivo situation, because GLUT-2 traffic to the brush border of enterocytes is regulated by endogenous hormones through PKC $\beta$ II activation, and this process is inactivated upon intestine explantation. A variable contribution by paracellular absorption may also take place; this can be altered/increased by stretching of the intestinal segment during the assembly of Ussing chambers, which in turn depends on the particular anatomical features of each explanted intestine. To gain more information on the absorption of derivative 2 , we thus performed in vivo pharmacokinetic experiments.

\subsection{In Vivo Pharmacokinetics}

Oral administration by gavage of derivative $\mathbf{2}$ to rats resulted in low concentrations of the derivative in the bloodstream during the 4 hours following administration; maximum levels were reached after about $60 \mathrm{~min}$ (Figure 1). This suggests that the paracellular pathway may not be involved in uptake, but the mechanism of absorption remains to be defined. Besides sugar carriers, other candidates are provided by the families of Organic Anion Transporter Polypeptides (OATPs) (e.g., [83-86]) and/or Organic Cation Transporters (OCTs) [87,88].

Neither resveratrol nor its common metabolites were present in detectable amounts either in the basolateral chamber in ex vivo assays or in the blood of rats after oral administration. It follows that while 2 can be transported across the intestinal wall, although with a low efficiency, it resists the 
action of hydrolytic enzymes in the gut, gut wall, blood and liver. Also derivative $\mathbf{3}$ exhibited complete stability at physiological $\mathrm{pH}$ values and in blood; one can thus conclude that $N, N$-disubstituted carbamate derivatives are stable under the conditions of interest here. The ideal bond in prodrugs needs on the other hand to have a finite lifetime in vivo. The stability of the carbamate ester group can be fine-tuned by acting on the substitution pattern of the $\mathrm{N}$ atom: $N$-monosubstituted carbamates are known to be less stable than $N, N$-disubstituted ones [89].

Figure 1. Results of pharmacokinetic experiments in rats with derivative 2. Blood concentration $v s$ time profile. Mean values \pm st. dev. $(n=5)$. To compare these results with the pharmacokinetic profile obtained administering resveratrol itself, please see [78].

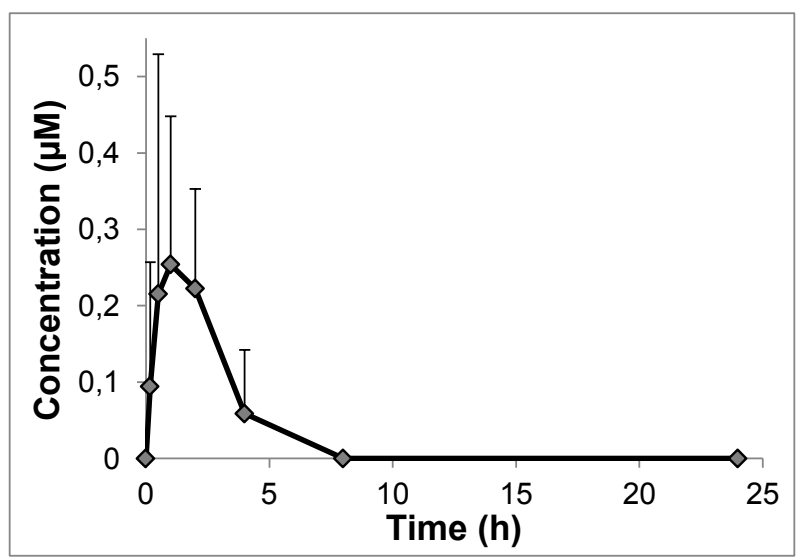

\section{Experimental Section}

\subsection{Materials, Reagents and Standard Procedures}

Resveratrol was purchased from Waseta Int. Trading Co. (Shangai, China). Other starting materials and reagents were purchased from Sigma-Aldrich, Fluka, Merck-Novabiochem, Riedel de Haen, J.T. Baker, Cambridge Isotope Laboratories Inc., Acros Organics, Carlo Erba and Prolabo, and were used as received. ${ }^{1} \mathrm{H}-\mathrm{NMR}$ spectra were recorded with a Bruker AC250F spectrometer operating at $250 \mathrm{MHz}$. Chemical shifts $(\delta)$ are given in ppm relative to the signal of the solvent. HPLC/ESI-MS analyses and mass spectra determinations were performed with a 1100 Series Agilent Technologies system, equipped with a binary pump (G1312A) and a MSD SL Trap mass spectrometer (G2445D SL) with an ESI source. Reaction intermediates and final purified products were injected as solutions in acetonitrile; elution was carried out with a water:acetonitrile $1: 1$ mixture containing $0.1 \%$ formic acid. TLCs were run on silica gel supported on plastic (Macherey-Nagel Polygram ${ }^{\circledR}$ SIL G/UV 254 , silica thickness $0.2 \mathrm{~mm}$ ), or on silica gel supported on glass (Fluka) (silica thickness $0.25 \mathrm{~mm}$, granulometry $60 \AA$, medium porosity) and visualized by UV detection or $\mathrm{KMnO}_{4}$ oxidation. Flash chromatography was performed on silica gel (Macherey-Nagel 60, 230-400 mesh granulometry (0.063-0.040 mm)) under air pressure. Solvents were analytical or synthetic grade and were used without further purification. Elemental analyses were carried out using a Fisons-EA-1108 CHNS-O Element Analyzer (Thermo Scientific). 


\subsection{Synthesis}

1,2,5,6-Di-O-isopropylidene-3-(4-chlorobutoxy)- $\alpha$-D-glucofuranose (5): $\mathrm{NaH}$ (0.31 g, 7.7 mmol, 2.0 eq., $60 \%$ in mineral oil) was washed three times with $5 \mathrm{~mL}$ of $n$-hexane. The suspension was decanted after each wash and $n$-hexane traces were removed under reduced pressure. Anhydrous DMF (15 mL) was then added and the suspension was stirred for $5 \mathrm{~min}$. A solution of 1,2,5,6-Di- $O$-isopropylidene- $\alpha-$ D-glucofuranose (4, $1.00 \mathrm{~g}, 3.8 \mathrm{mmol}, 1.0$ eq.) in anhydrous DMF (15 mL) was then added dropwise. After stirring for $30 \mathrm{~min}$ under nitrogen flow, a solution of 1-bromo-4-chlorobutane (2.63 g, $15.4 \mathrm{mmol}$, 4.0 eq.) in anhydrous DMF ( $5 \mathrm{~mL}$ ) was added dropwise and the mixture was vigorously stirred for 24 hours at $40{ }^{\circ} \mathrm{C}$. The reaction mixture was then diluted in $\mathrm{CH}_{2} \mathrm{Cl}_{2}(150 \mathrm{~mL})$ and washed with $0.3 \mathrm{~N} \mathrm{HCl}$ $(5 \times 100 \mathrm{~mL})$. The organic layer was dried over $\mathrm{MgSO}_{4}$ and filtered. The solvent was evaporated under reduced pressure and the residue was purified by column chromatography $\left(\mathrm{CH}_{2} \mathrm{Cl}_{2}\right.$ :EtOAc 9:1) to give $5(0.81 \mathrm{~g}, 60 \%$ yield $)$ as a pale yellow oil. ${ }^{1} \mathrm{H}-\mathrm{NMR}\left(\mathrm{CDCl}_{3}\right) \delta(\mathrm{ppm})=5.87(\mathrm{~d}, J=3.7 \mathrm{~Hz}, 1 \mathrm{H},-\mathrm{CH}-)$, 4.53 (d, $J=3.8 \mathrm{~Hz}, 1 \mathrm{H},-\mathrm{CH}-), 4.32-4.24$ (m, 1H, -CH-), 4.12-4.06 (m, 2H, - $\mathrm{CH}_{2}-$ ), 4.00-3.95 (m, 1H, -CH-), 3.86-3.44 (m, 5H, -CH-, -O- $\left.\mathrm{CH}_{2-},-\mathrm{CH}_{2}-\mathrm{Cl}\right), 1.84-1.60$ (m, 4H, $-\mathrm{CH}_{2}-\mathrm{CH}_{2}$ ) , 1.49, 1.41, 1.34, $1.31\left(4 \mathrm{~s}, 12 \mathrm{H}, 4 \times-\mathrm{CH}_{3}\right) ;{ }^{13} \mathrm{C}-\mathrm{NMR}\left(\mathrm{CDCl}_{3}\right) \delta(\mathrm{ppm})=111.76,108.98,105.25,83.05,82.12,81.21$, 72.34, 69.54, 67.39, 44.76, 29.26, 26.99, 26.80, 26.77, 26.21, 25.34; ESI-MS (ion trap): $\mathrm{m} / z 351$ $[\mathrm{M}+\mathrm{H}]^{+}$. Anal. calcd. for $\mathrm{C}_{16} \mathrm{H}_{27} \mathrm{ClO}_{6}$ : C, 54.78; H, 7.76 Found: C, 54.69; H, 7.71.

1,2,5,6-Di-O-isopropylidene-3-(4-N-methyl-N-butoxyamino)- $\alpha$-D-glucofuranose $\quad(6): \quad$ In $\quad$ a sealed microwave reactor 5 (1.99 g, $5.7 \mathrm{mmol}, 1.0$ eq.) was added to methylamine solution (33 wt. \% in absolute EtOH, $25 \mathrm{~mL}, 198.5 \mathrm{mmol}, 35.0$ eq.). The reaction mixture was stirred for $30 \mathrm{~min}$ under microwave irradiation $\left(150^{\circ} \mathrm{C}, 150 \mathrm{~W}\right)$. The solvent was evaporated under reduced pressure and the residue was purified by column chromatography $\left(\mathrm{CH}_{2} \mathrm{Cl}_{2} / \mathrm{MeOH} 8.5: 1.5\right)$ to give 6 (1.78 g, 91\% yield) as a white solid. ${ }^{1} \mathrm{H}-\mathrm{NMR}\left(\mathrm{DMSO}-d_{6}\right) \delta(\mathrm{ppm})=5.83(\mathrm{~d}, J=3.7 \mathrm{~Hz}, 1 \mathrm{H},-\mathrm{CH}-), 4.63(\mathrm{~d}, J=3.8 \mathrm{~Hz}$, $1 \mathrm{H},-\mathrm{CH}-), 4.27-4.20$ (m, 1H, -CH-), 4.04-3.94 (m, 2H, - $\left.\mathrm{CH}_{2}-\right), 3.84-3.74\left(\mathrm{~m}, 2 \mathrm{H},-\mathrm{CH}_{2}-\right), 3.64-3.56$ (m, 1H, -CH-), 3.46-3.32 (m, 4H, -CH-, -NH-CH $), 2.90-2.76$ (m, 2H, -NH-CH $\left.2_{2}\right), 2.43$ (br, 1H, -NH-), $1.72-1.48\left(\mathrm{~m}, 4 \mathrm{H},-\mathrm{CH}_{2}-\mathrm{CH}_{2}-\right), 1.39,1.32,1.27,1.25\left(4 \mathrm{~s}, 12 \mathrm{H}, 4 \times-\mathrm{CH}_{3}\right) ;{ }^{13} \mathrm{C}-\mathrm{NMR}$ (DMSO- $\left.d_{6}\right) \delta$ $(\mathrm{ppm})=110.78,107.98,104.67,81.56,81.48,80.28,72.29,68.72,65.93,47.83,32.18,26.65,26.61$, 26.22, 26.08, 25.32, 22.26; ESI-MS (ion trap): $m / z 346[\mathrm{M}+\mathrm{H}]^{+}$. Anal. calcd. for $\mathrm{C}_{17} \mathrm{H}_{31} \mathrm{NO}_{6}$ : C, 59.11; H, 9.05; N, 4.05 Found: C, 59.15; H, 9.01; N, 4.11.

\section{3,4',5-Tri-[1,2,5,6-Di-O-isopropylidene- $\alpha$-D-glucofuranose-3-(4-N-methyl-N-butoxy)]-resveratrol} carbamate (8): A solution of $6\left(2.03 \mathrm{~g}, 5.9 \mathrm{mmol}, 1.0\right.$ eq.) and pyridine $(5.0 \mathrm{~mL})$ in $\operatorname{dry} \mathrm{CH}_{2} \mathrm{Cl}_{2}(20 \mathrm{~mL})$ was slowly added to triphosgene $(1.74 \mathrm{~g}, 5.9 \mathrm{mmol}, 1.0$ eq. $)$ in dry $\mathrm{CH}_{2} \mathrm{Cl}_{2}(20 \mathrm{~mL})$ at $0{ }^{\circ} \mathrm{C}$. The mixture was stirred at room temperature for $45 \mathrm{~min}$ followed by addition of $0.1 \mathrm{~N} \mathrm{HC1}(50.0 \mathrm{~mL})$. The organic layer was separated, and washed $4 \times 100 \mathrm{~mL}$ with $0.1 \mathrm{~N} \mathrm{HCl}$ and then dried over $\mathrm{MgSO}_{4}$, filtered and concentrated under reduced pressure. The residue was then filtered through a short silica-gel column $\left(\mathrm{CH}_{2} \mathrm{Cl}_{2}\right.$ :EtOAc $\left.8.25: 1.75\right)$ and the eluate concentrated to give 7 as a pale yellow oil, which was used immediately without further purification. Compound 7 (1.70 g, $4.2 \mathrm{mmol}, 5$ eq.) was then added to a solution of resveratrol (1, $0.190 \mathrm{~g}, 0.8 \mathrm{mmol}, 1$ eq.) and DMAP (0.407 g, $3.3 \mathrm{mmol}, 4$ eq. $)$ in pyridine $(5 \mathrm{~mL})$ and the resulting solution was vigorously stirred for 16 hours at $135{ }^{\circ} \mathrm{C}$. The reaction 
mixture was then diluted in EtOAc $(150 \mathrm{~mL})$ and washed with $0.5 \mathrm{~N} \mathrm{HCl}(5 \times 100 \mathrm{~mL})$. The organic layer was dried over $\mathrm{MgSO}_{4}$ and filtered. The solvent was evaporated under reduced pressure and the residue was purified by column chromatography $\left(\mathrm{CH}_{2} \mathrm{Cl}_{2}\right.$ :EtOAc 5.5:4.5) to give 8 (0.86 g, 76\% yield) as a white solid. ${ }^{1} \mathrm{H}-\mathrm{NMR}\left(\mathrm{CDCl}_{3}\right) \delta(\mathrm{ppm})=7.46(\mathrm{~d}, J=8.6 \mathrm{~Hz}, 2 \mathrm{H}, 2 \times \mathrm{Ar}-\mathrm{H}), 7.17-6.92(\mathrm{~m}, 6 \mathrm{H}, 6$ $\times$ Ar-H), 6.89-6.81 (m, 1H, Ar-H), 5.87 (d, $J=3.7 \mathrm{~Hz}, 3 \mathrm{H}, 3 \times-\mathrm{CH}-), 4.58-4.50$ (m, 3H, $3 \times-\mathrm{CH}-)$, 4.35-4.27 (m, 3H, $3 \times-\mathrm{CH}-)$, 4.15-3.96 (m, 9H, $\left.3 \times-\mathrm{CH}-, 3 \times-\mathrm{CH}_{2}-\right)$, 3.89-3.84 (m, 3H, $\left.3 \times-\mathrm{CH}-\right)$, 3.72-3.52 (m, 6H, $\left.3 \times-\mathrm{CON}\left(\mathrm{CH}_{3}\right)-\mathrm{CH}_{2}-\right), 3.48-3.32\left(\mathrm{~m}, 6 \mathrm{H}, 3 \times-\mathrm{O}-\mathrm{CH}_{2}-\right), 3.10-2.96(2 \mathrm{~s}, 9 \mathrm{H}, 3 \times-$ $\mathrm{CON}\left(\mathrm{CH}_{3}\right)-, 1.77-1.55\left(\mathrm{~m}, 12 \mathrm{H}, 3 \times-\mathrm{CH}_{2}-\mathrm{CH}_{2}-\right), 1.49,1.42,1.35,1.31\left(4 \mathrm{~s}, 36 \mathrm{H}, 12 \times-\mathrm{CH}_{3}\right) ;{ }^{13} \mathrm{C}-$ $\operatorname{NMR}\left(\mathrm{CDCl}_{3}\right) \delta(\mathrm{ppm})=154.73,154.42,151.07,150.78$ 127.61, 122.09, 116.59, 111.89, 111.81, 109.94, 109.10, 105.38, 82.57, 82.28, 81.28, 72.58, 70.18, 70.15, 67.43, 49.19, 49.09, 31.09, 26.96, 26.34, 25.57; ESI-MS (ion trap): $m / z 1365[\mathrm{M}+\mathrm{H}]^{+}$. Anal. calcd. for $\mathrm{C}_{68} \mathrm{H}_{99} \mathrm{~N}_{3} \mathrm{O}_{24}: \mathrm{C}, 60.84 ; \mathrm{H}, 7.43 ; \mathrm{N}$, 3.13 Found: C, $60.77 ; \mathrm{H}, 7.40 ; \mathrm{N}, 3.08$.

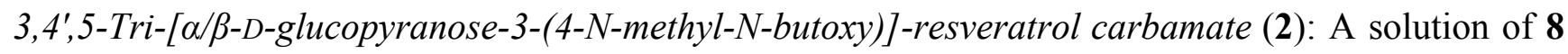
$(0.30 \mathrm{~g}, 0.2 \mathrm{mmol})$, trifluoroacetic acid $(1.8 \mathrm{~mL})$, and water $(0.2 \mathrm{~mL})$ was stirred for 1.5 hours at room temperature. The reaction mixture was then added dropwise to diethyl ether $(10 \mathrm{~mL})$ under stirring and the precipitate was centrifuged $(1000 \mathrm{~g}, 5 \mathrm{~min})$. The solvent was decanted and the precipitate was washed three times with diethyl ether $(10 \mathrm{~mL})$ in order to eliminate residual traces of trifluoroacetic acid. The resulting solid was dissolved in water $(5 \mathrm{~mL})$ and lyophilized to give $2(0.23 \mathrm{~g}, 93 \%$ yield) as a bright white solid. ${ }^{1} \mathrm{H}-\mathrm{NMR}\left(\mathrm{DMSO}-d_{6}\right) \delta(\mathrm{ppm})=7.61(\mathrm{~d}, J=8.6 \mathrm{~Hz}, 2 \mathrm{H}, 2 \times \mathrm{Ar}-\mathrm{H}), 7.37-6.11(\mathrm{~m}$, $6 \mathrm{H}, 6 \times \mathrm{Ar}-\mathrm{H}), 6.89-6.81(\mathrm{~m}, 1 \mathrm{H}, \mathrm{Ar}-\mathrm{H}), 4.89$ (d, $J=3.7 \mathrm{~Hz}, 3 \mathrm{H}, 3 \times-\mathrm{CH}-), 4.28(\mathrm{~d}, J=7.0 \mathrm{~Hz}, 3 \mathrm{H}, 3 \times$ -CH-), 3.79-2.86 (m, 36H), 1.75-1.43 (m, 12H, $\left.3 \times-\mathrm{CH}_{2}-\mathrm{CH}_{2}-\right) ;{ }^{13} \mathrm{C}-\mathrm{NMR}\left(\mathrm{CDCl}_{3}\right) \delta(\mathrm{ppm})=153.69$, $153.48,151.82,150.94,138.76,133.57,132.62,127.39,126.63,122.16,96.84,92.27,85.16,81.90$, 76.64, 74.51, 72.03, 71.44, 71.43, 71.41, 71.40, 71.38, 69.85, 69.83, 69.66, 69.65, 61.00, 48.54, 34.43, 34.13, 26.99, 26.97; ESI-MS (ion trap): $m / z 1124.5[\mathrm{M}+\mathrm{H}]^{+}$. Anal. calcd. for $\mathrm{C}_{50} \mathrm{H}_{75} \mathrm{~N}_{3} \mathrm{O}_{24}$ : C, 54.49; $\mathrm{H}$, 6.86 ; N, 3.81 Found: C, 54.54; H, 6.84; N, 3.71.

(Methoxypolyethylene glycol 350)-p-toluenesulfonate (10): A solution of sodium hydroxide (2.29 g, $57.3 \mathrm{mmol}, 2.0$ eq.) in water $(20 \mathrm{ml})$ and $\mathrm{mPEG}-350(\mathbf{9}, 10.0 \mathrm{~g}, 28.6 \mathrm{mmol}, 1$ eq. $)$ in THF (20 mL) was cooled in an ice-water bath with stirring and tosyl chloride (10.9 g, $57.3 \mathrm{mmol}, 2$ eq.) in THF (20 ml) was added dropwise over 2 hours. The reaction mixture was stirred for an additional 2 hours at $5{ }^{\circ} \mathrm{C}$, poured into ice-water $(100 \mathrm{~mL})$ and extracted with $\mathrm{CH}_{2} \mathrm{Cl}_{2}(3 \times 100 \mathrm{~mL})$. The combined organic extracts were dried over $\mathrm{MgSO}_{4}$ and filtered. The solvent was evaporated under reduced pressure and the residue was purified by column chromatography $\left(\mathrm{CHCl}_{3}: \mathrm{MeOH}\right.$ 9.9:0.1 and increasing methanol content) to give $10\left(11.03 \mathrm{~g}, 77 \%\right.$ yield) as a colourless oil. ${ }^{1} \mathrm{H}-\mathrm{NMR}\left(\mathrm{CDCl}_{3}\right) \delta(\mathrm{ppm})=7.78(\mathrm{~d}, J=8.3 \mathrm{~Hz}, 2 \mathrm{H}, 2$ $\times \mathrm{Ar}-\mathrm{H}), 7.33(\mathrm{~d}, J=8.3 \mathrm{~Hz}, 2 \mathrm{H}, 2 \times \mathrm{Ar}-\mathrm{H}), 4.15\left(\mathrm{t}, J=4.90 \mathrm{~Hz}, 2 \mathrm{H},-\left(\mathrm{SO}_{2}\right) \mathrm{O}-\mathrm{CH}_{2}-\right), 3.70-3.51(\mathrm{~m}, 30 \mathrm{H}$, $\left.7 \times-\mathrm{O}-\mathrm{CH}_{2}-\mathrm{CH}_{2}-\mathrm{O}-+-\mathrm{O}-\mathrm{CH}_{2}-\right), 3.37\left(\mathrm{~s}, 3 \mathrm{H},-\mathrm{O}-\mathrm{CH}_{3}\right), 2.44\left(\mathrm{~s}, 3 \mathrm{H}, \mathrm{Ar}-\mathrm{CH}_{3}\right) ;{ }^{13} \mathrm{C}-\mathrm{NMR}\left(\mathrm{CDCl}_{3}\right) \delta(\mathrm{ppm})$ $=144.74,132.90,129.77,127.93,71.87,70.68,70.54,70.50,70.46,69.20,68.62,58.98,21.62$; ESIMS (ion trap): $m / z 495\left[\mathrm{M}_{(n=7)}+\mathrm{H}\right]^{+}$.

$N$-methyl-N-(methoxypolyethylene glycol 350) amine (11): In a sealed microwave reactor 10 (5.43 g, $10.1 \mathrm{mmol}, 1.0$ eq.) was added to methylamine solution (33 wt. \% in absolute ethanol, $44 \mathrm{~mL}, 353.5$ 
mmol, 35.0 eq.). The reaction mixture was stirred for $30 \mathrm{~min}$ under microwave irradiation $\left(150{ }^{\circ} \mathrm{C}, 150 \mathrm{~W}\right)$. After evaporation of the solvent, the residue was dissolved in $5 \% \mathrm{HCl}(20 \mathrm{~mL})$ and extracted with $\mathrm{CHCl}_{3}(3 \times 20 \mathrm{~mL})$. The $\mathrm{CHCl}_{3}$ extracts were washed separately with $5 \% \mathrm{HCl}(2 \times 10 \mathrm{~mL})$ and all the $\mathrm{HCl}$ fractions were combined, $30 \%$ sodium hydroxide $(15 \mathrm{~mL})$ was added and the resulting solution was extracted with chloroform $(3 \times 25 \mathrm{~mL})$. The chloroform extracts were then washed separately with water $(10 \mathrm{~mL})$. The organic layer was dried over $\mathrm{MgSO}_{4}$ and filtered. The solvent was then evaporated under reduced pressure to give $\mathbf{1 1}$ as a pale yellow oil (3.60 g, 98\% yield). ${ }^{1} \mathrm{H}-\mathrm{NMR}\left(\mathrm{CDCl}_{3}\right) \delta(\mathrm{ppm})$ $=3.70-3.51\left(\mathrm{~m}, 30 \mathrm{H}, 7 \times-\mathrm{O}-\mathrm{CH}_{2}-\mathrm{CH}_{2}-\mathrm{O}-+-\mathrm{O}-\mathrm{CH}_{2}-\right), 3.36\left(\mathrm{~s}, 3 \mathrm{H},-\mathrm{O}-\mathrm{CH}_{3}\right), 2.74(\mathrm{t}, J=4.90 \mathrm{~Hz}, 2 \mathrm{H}$, $\left.-\mathrm{NH}-\mathrm{CH}_{2}-\right), 2.43\left(\mathrm{~s}, 3 \mathrm{H},-\mathrm{NH}-\mathrm{CH}_{3}\right), 2.16(\mathrm{~s}, 1 \mathrm{H},-\mathrm{NH}-) ;{ }^{13} \mathrm{C}-\mathrm{NMR}\left(\mathrm{CDCl}_{3}\right) \delta(\mathrm{ppm})=71.86,70.53$, 70.50, 70.42, 70.24, 70.07, 58.97, 51.11, 36.15; ESI-MS (ion trap): $m / z 354\left[\mathrm{M}_{(n=7)}+\mathrm{H}\right]^{+}$.

3,4',5-Tri-[N-methyl-N-(methoxypolyethylene glycol 350)]-resveratrol carbamate (3): A solution of 11 (3.70 g, $10.2 \mathrm{mmol}, 1.0$ eq.) and pyridine $(5.0 \mathrm{~mL})$ in dry $\mathrm{CH}_{2} \mathrm{Cl}_{2}(20 \mathrm{~mL})$ was slowly added to triphosgene (3.02 g, $10.2 \mathrm{mmol}, 1.0$ eq.) in dry $\mathrm{CH}_{2} \mathrm{Cl}_{2}(34 \mathrm{~mL})$ at $0{ }^{\circ} \mathrm{C}$. The mixture was stirred at room temperature for $45 \mathrm{~min}$, followed by addition of $0.1 \mathrm{~N} \mathrm{HCl}(50 \mathrm{~mL})$. The organic layer was separated, washed with $0.1 \mathrm{~N} \mathrm{HCl}(4 \times 100 \mathrm{~mL})$ and then dried over $\mathrm{MgSO}_{4}$, filtered and concentrated under reduced pressure. The residue was then filtered through a short silica-gel column $\left(\mathrm{CH}_{2} \mathrm{Cl}_{2}: \mathrm{MeOH}\right.$ 9:1) and the eluate concentrated to give $\mathbf{1 2}$ as a pale yellow oil, which was used immediately without further purification. 12 (1.77 g, $4.2 \mathrm{mmol}, 5$ eq.) was added to a solution of resveratrol (1, $0.190 \mathrm{~g}, 0.8 \mathrm{mmol}, 1$ eq.) and DMAP (0.407 g, $3.3 \mathrm{mmol}, 4$ eq.) in pyridine $(5 \mathrm{~mL})$ and the resulting solution was vigorously stirred for 16 hours at $135^{\circ} \mathrm{C}$. The reaction mixture was then diluted in EtOAc $(150 \mathrm{~mL})$ and washed with $0.5 \mathrm{~N} \mathrm{HCl}(5 \times 100 \mathrm{~mL})$. The organic layer was dried over $\mathrm{MgSO}_{4}$ and filtered. The solvent was evaporated under reduced pressure and the residue was purified by column chromatography (eluent: ACN) to give $3(0.88 \mathrm{~g}, 76 \%$ yield) as a colourless oil. ${ }^{1} \mathrm{H}-\mathrm{NMR}\left(\mathrm{CDCl}_{3}\right) \delta(\mathrm{ppm})=7.45(\mathrm{~d}, J=8.6 \mathrm{~Hz}, 2 \mathrm{H}, 2 \times \mathrm{Ar}-\mathrm{H}), 7.26-6.97(\mathrm{~m}, 6 \mathrm{H}, 6 \times \mathrm{Ar}-\mathrm{H}), 6.92-6.83$ (m, $1 \mathrm{H}, \mathrm{Ar}-\mathrm{H}), 3.71-3.52\left(\mathrm{~m}, 9 \mathrm{H}, 21 \times-\mathrm{O}_{-} \mathrm{CH}_{2}-\mathrm{CH}_{2}-\mathrm{O}-, 3 \times-\mathrm{O}-\mathrm{CH}_{2}-, 3 \times-\mathrm{CON}\left(\mathrm{CH}_{3}\right)-\mathrm{CH}_{2}-\right), 3.37(\mathrm{~s}, 9 \mathrm{H}$, $\left.3 \times-\mathrm{O}-\mathrm{CH}_{3}\right), 3.15-3.07\left(2 \mathrm{~s}, 9 \mathrm{H}, 3 \times-\mathrm{NH}-\mathrm{CH}_{3}\right), 2.16(\mathrm{~s}, 1 \mathrm{H},-\mathrm{NH}-) ;{ }^{13} \mathrm{C}-\mathrm{NMR}\left(\mathrm{CDCl}_{3}\right) \delta(\mathrm{ppm})=$ $154.33,154.17,151.93,151.07,139.11,133.99,129.29,129.23,127.39,127.16,127.13,121.94$, 116.43, 116.41, 71.88, 70.53, 70.48, 69.71, 69.32, 59.03, 59.00, 49.12, 49.07, 48.98, 36.04; ESI-MS (ion trap): $m / z 1367\left[\mathrm{M}_{(n=7)}+\mathrm{H}\right]^{+}$.

\subsection{Permeation Studies with Rat Intestinal Segments (Ex Vivo)}

All experiments involving animals were performed with the permission and supervision of the University of Padova Ethical Committee for Experimentation on Animals (CEASA) and Central Veterinary Service, in compliance with Italian Law DL 116/92, embodying UE Directive 86/609.

Intestine was excised from $18 \mathrm{~h}$ fasted rats and transferred into a saline solution $(154 \mathrm{mM} \mathrm{NaCl}$ in water) at $37^{\circ} \mathrm{C}$. The jejunum was cut into $1 \mathrm{~cm}$ long strips, opened longitudinally, rinsed free of luminal content and mounted in Ussing-type chambers. Apical and basolateral compartments were filled with $1 \mathrm{~mL}$ each of oxygenated HEPES buffer $(248 \mathrm{mM} \mathrm{NaCl}, 55.3 \mathrm{mM}$ glucose, $50 \mathrm{mM} \mathrm{NaHCO} 3,9.9$ $\mathrm{mM} \mathrm{KCl}, 1.9 \mathrm{mM} \mathrm{MgSO}_{4}, 40 \mathrm{mM}$ HEPES, $\mathrm{pH}$ 6.8), and incubated in a water bath at $37{ }^{\circ} \mathrm{C}$ until all chambers were assembled (approximately $20 \mathrm{~min}$ ). The buffer was then removed and substituted with 
$1 \mathrm{~mL}$ of a $20 \mu \mathrm{M}$ solution (in the same buffer) of the compound to be tested on the apical side (dilution from a $20 \mathrm{mM}$ stock solution), and with $1 \mathrm{~mL}$ of fresh HEPES buffer on the basolateral one. Stock solutions of the compounds were prepared in water (for the derivatives) or in DMSO (for resveratrol, due to its limited water solubility). During the experiment, oxygen was continuously bubbled in each basolateral compartment. An aliquot of the initial apical solutions was incubated separately at $37{ }^{\circ} \mathrm{C}$ for the period of the experiment, to verify the stability of each compound in the absence of jejunum. At the end of the experiment $(2.5 \mathrm{~h}), 800 \mu \mathrm{L}$ of chamber contents from apical and basolateral sides were collected and mixed with $8 \mu \mathrm{L}$ of $100 \mathrm{mM}$ ascorbic acid in water and $8 \mu \mathrm{L}$ of $6 \mathrm{M}$ acetic acid. The samples were then centrifuged $\left(12,000 \times \mathrm{g}, 7 \mathrm{~min}, 4^{\circ} \mathrm{C}\right)$, and supernatants were frozen and maintained at $-20^{\circ} \mathrm{C}$ until HPLC-UV analysis (see below).

\subsection{Pharmacokinetic Studies}

Derivative 2 was administered to overnight-fasted male Wistar rats from the facility of the Department of Biomedical Sciences as a single intragastric dose $(88 \mu \mathrm{mol} / \mathrm{kg}$, dissolved in $250 \mu \mathrm{L}$ water). Blood samples were obtained by the tail bleeding technique: before drug administration, rats were anesthetised with isoflurane and the tip of the tail was cut off; blood samples (80-100 $\mu \mathrm{L}$ each) were then taken from the tail tip at different time points after drug administration. Blood was collected in heparinised tubes, kept in ice and treated as described in [90] within $10 \mathrm{~min}$.

\subsection{HPLC-UV Analysis}

Samples $(2 \mu \mathrm{L})$ were analyzed by HPLC/UV (1290 Infinity LC System, Agilent Technologies) using a reverse phase column (Zorbax RRHD Eclipse Plus C18, $1.8 \mu \mathrm{m}, 50$ x $2.1 \mathrm{~mm}$ i.d.; Agilent Technologies) and a UV diode array detector (190-500 nm). Solvents A and B were water containing $0.1 \%$ trifluoroacetic acid (TFA) and acetonitrile, respectively. The gradient for B was as follows: $22 \%$ for $0.2 \mathrm{~min}$, from $22 \%$ to $30 \%$ in $1.2 \mathrm{~min}$, then from $30 \%$ to $100 \%$ in $1.2 \mathrm{~min}$; the flow rate was $0.6 \mathrm{~mL} / \mathrm{min}$. The temperature of the column was kept at $35^{\circ} \mathrm{C}$.

The eluate was monitored at 300 or $320 \mathrm{~nm}$, corresponding to absorbance maxima of derivatives (2 and 3$)$ and resveratrol, respectively. The absorption coefficients $\left(\varepsilon_{300}, \varepsilon_{320}\right)$ of resveratrol derivatives, resveratrol and metabolites are very similar. For quantification purposes we assumed the same absorption coefficient.

\subsection{Statistics}

Significance in comparisons was assessed using the Wilcoxon Rank Test.

\section{Conclusions}

The work presented here shows that sugar groups can be attached to resveratrol, thus making it completely soluble in water - a significant feature - while maintaining to some degree the ability to permeate biomembranes. The next goal may thus be that of producing carbamate derivatives carrying a single substituent on the nitrogen atom, designed to result in a permeant molecule with a lifetime compatible with its intended function as a prodrug. 


\section{Acknowledgments}

We thank M. Ghidotti for technical help and NÓOS Srl for generous support and consultations. This work was also supported by grants from the Fondazione Cassa di Risparmio di Padova e Rovigo (CARIPARO) ("Developing a Pharmacology of Polyphenols"), from the Italian Ministry of the University and Research (PRIN n. 20107Z8XBW_004), and by the CNR Project of Special Interest on Aging.

\section{Author Contributions}

All authors contributed to the design and conduction of the work and to writing the manuscript.

\section{Conflicts of Interest}

The authors declare no conflict of interest.

\section{References}

1. Harikumar, K.B.; Aggarwal, B.B. Resveratrol: A multitargeted agent for age-associated chronic diseases. Cell Cycle 2008, 7, 1020-1035.

2. Pervaiz, S.; Holme, A.L. Resveratrol: Its biologic targets and functional activity. Antioxid. Redox Sign. 2009, 11, 2851-2897.

3. Biasutto, L.; Szabo, I.; Zoratti, M. Mitochondrial effects of plant-made compounds. Antioxid. Redox Sign. 2011, 15, 3039-3059.

4. Biasutto, L.; Mattarei, A.; Zoratti, M. Resveratrol and health: the starting point. ChemBioChem 2012, 13, 1256-1259.

5. McCalley, A.E.; Kaja, S.; Payne, A.J.; Koulen, P. Resveratrol and calcium signaling: Molecular mechanisms and clinical relevance. Molecules 2014, 19, 7327-7340.

6. Wang, S.; Moustaid-Moussa, N.; Chen, L.; Mo, H.; Shastri, A.; Su, R.; Bapat, P.; Kwun, I.; Shen, C.L. Novel insights of dietary polyphenols and obesity. J. Nutr. Biochem. 2014, 25, 1-18.

7. Pallas, M.; Porquet, D.; Vicente, A.; Sanfeliu, C. Resveratrol: New avenues for a natural compound in neuroprotection. Curr. Pharm. Des. 2013, 19, 6726-6731.

8. Widlund, A.L.; Baur, J.A.; Vang, O. mTOR: More targets of resveratrol? Expert Rev. Mol. Med. 2013, 15, doi:10.1017/erm.2013.11.

9. Park, S.J.; Ahmad, F.; Philp, A.; Baar, K.; Williams, T.; Luo, H.; Ke, H.; Rehmann, H.; Taussig, R.; Brown, A.L.; et al. Resveratrol ameliorates aging-related metabolic phenotypes by inhibiting cAMP phosphodiesterases. Cell 2012, 148, 421-433.

10. Wang, Y.; Li, Y.; Liu, X.; Cho, W.C. Genetic and epigenetic studies for determining molecular targets of natural product anticancer agents. Curr. Cancer Drug Targets 2013, 13, 506-518.

11. Um, J.H.; Park, S.J.; Kang, H.; Yang, S.; Foretz, M.; McBurney, M.W.; Kim, M.K.; Viollet, B.; Chung, J.H. AMP-activated protein kinase-deficient mice are resistant to the metabolic effects of resveratrol. Diabetes 2010, 59, 554-563.

12. Price, N.L.; Gomes, A.P.; Ling, A.J.; Duarte, F.V.; Martin-Montalvo, A.; North, B.J.; Agarwal, B.; Ye, L.; Ramadori, G.; Teodoro, J.S.; et al. SIRT1 is required for AMPK activation and the beneficial effects of resveratrol on mitochondrial function. Cell Metab. 2012, 15, 675-690. 
13. Azorin-Ortuno, M.; Yanez-Gascon, M.J.; Vallejo, F.; Pallares, F.J.; Larrosa, M.; Lucas, R.; Morales, J.C.; Tomas-Barberan, F.A.; Garcia-Conesa, M.T.; Espin, J.C. Metabolites and tissue distribution of resveratrol in the pig. Mol. Nutr. Food Res. 2011, 55, 1154-1168.

14. Abd El-Mohsen, M.; Bayele, H.; Kuhnle, G.; Gibson, G.; Debnam, E.; Srai, S.K.; Rice-Evans, C.; Spencer, J.P. Distribution of $[3 \mathrm{H}]$ trans-resveratrol in rat tissues following oral administration. $\mathrm{Br}$. J. Nutr. 2006, 96, 62-70.

15. Juan, M.E.; Maijo, M.; Planas, J.M. Quantification of trans-resveratrol and its metabolites in rat plasma and tissues by HPLC. J. Pharm. Biomed. Anal. 2010, 51, 391-398.

16. Walle, T.; Hsieh, F.; DeLegge, M.H.; Oatis, J.E., Jr.; Walle, U.K. High absorption but very low bioavailability of oral resveratrol in humans. Drug Metab. Dispos. 2004, 32, 1377-1382.

17. Azzolini, M.; Spina, M.L.; Mattarei, A.; Paradisi, C.; Zoratti, M.; Biasutto, L. Pharmacokinetics and tissue distribution of pterostilbene in the rat. Mol. Nutr. Food Res. 2014, doi:10.1002/mnfr.201400244.

18. Walle, T. Bioavailability of resveratrol. Ann. N. Y. Acad. Sci. 2011, 1215, 9-15.

19. Planas, J.M.; Alfaras, I.; Colom, H.; Juan, M.E. The bioavailability and distribution of transresveratrol are constrained by ABC transporters. Arch. Biochem. Biophys. 2012, 527, 67-73.

20. Kaldas, M.I.; Walle, U.K.; Walle, T. Resveratrol transport and metabolism by human intestinal Caco-2 cells. J. Pharm. Pharmacol. 2003, 55, 307-312.

21. Wenzel, E.; Somoza, V. Metabolism and bioavailability of trans-resveratrol. Mol. Nutr. Food Res. 2005, 49, 472-481.

22. Bode, L.M.; Bunzel, D.; Huch, M.; Cho, G.S.; Ruhland, D.; Bunzel, M.; Bub, A.; Franz, C.M.; Kulling, S.E. In vivo and in vitro metabolism of trans-resveratrol by human gut microbiota. Am. J. Clin. Nutr. 2013, 97, 295-309.

23. Yu, C.; Shin, Y.G.; Chow, A.; Li, Y.; Kosmeder, J.W.; Lee, Y.S.; Hirschelman, W.H.; Pezzuto, J.M.; Mehta, R.G.; van Breemen, R.B. Human, rat, and mouse metabolism of resveratrol. Pharm. Res. 2002, 19, 1907-1914.

24. Maier-Salamon, A.; Bohmdorfer, M.; Thalhammer, T.; Szekeres, T.; Jaeger, W. Hepatic glucuronidation of resveratrol: Interspecies comparison of enzyme kinetic profiles in human, mouse, rat, and dog. Drug Metab. Pharmacokinet. 2011, 26, 364-373.

25. Menet, M.C.; Marchal, J.; Dal-Pan, A.; Taghi, M.; Nivet-Antoine, V.; Dargere, D.; Laprevote, O.; Beaudeux, J.L.; Aujard, F.; Epelbaum, J.; et al. Resveratrol metabolism in a non-human primate, the grey mouse lemur (Microcebus murinus), using ultra-high-performance liquid chromatographyquadrupole time of flight. PLoS One 2014, 9, e91932.

26. Dellinger, R.W.; Garcia, A.M.; Meyskens, F.L., Jr. Differences in the glucuronidation of resveratrol and pterostilbene: Altered enzyme specificity and potential gender differences. Drug Metab. Pharmacokinet. 2014, 29, 112-119.

27. Miksits, M.; Wlcek, K.; Svoboda, M.; Kunert, O.; Haslinger, E.; Thalhammer, T.; Szekeres, T.; Jager, W. Antitumor activity of resveratrol and its sulfated metabolites against human breast cancer cells. Planta Med. 2009, 75, 1227-1230.

28. Calamini, B.; Ratia, K.; Malkowski, M.G.; Cuendet, M.; Pezzuto, J.M.; Santarsiero, B.D.; Mesecar, A.D. Pleiotropic mechanisms facilitated by resveratrol and its metabolites. Biochem. J. 2010, 429, 273-282. 
29. Hoshino, J.; Park, E.J.; Kondratyuk, T.P.; Marler, L.; Pezzuto, J.M.; van Breemen, R.B.; Mo, S.; Li, Y.; Cushman, M. Selective synthesis and biological evaluation of sulfate-conjugated resveratrol metabolites. J. Med. Chem. 2010, 53, 5033-5043.

30. Lasa, A.; Churruca, I.; Eseberri, I.; Andres-Lacueva, C.; Portillo, M.P. Delipidating effect of resveratrol metabolites in 3T3-L1 adipocytes. Mol. Nutr. Food Res. 2012, 56, 1559-1568.

31. Ruotolo, R.; Calani, L.; Fietta, E.; Brighenti, F.; Crozier, A.; Meda, C.; Maggi, A.; Ottonello, S.; Del Rio, D. Anti-estrogenic activity of a human resveratrol metabolite. Nutr. Metab. Cardiovasc. Dis. 2013, 23, 1086-1092.

32. Aires, V.; Limagne, E.; Cotte, A.K.; Latruffe, N.; Ghiringhelli, F.; Delmas, D. Resveratrol metabolites inhibit human metastatic colon cancer cells progression and synergize with chemotherapeutic drugs to induce cell death. Mol. Nutr. Food Res. 2013, 57, 1170-1181.

33. Walker, J.; Schueller, K.; Schaefer, L.M.; Pignitter, M.; Esefelder, L.; Somoza, V. Resveratrol and its metabolites inhibit pro-inflammatory effects of lipopolysaccharides in U-937 macrophages in plasma-representative concentrations. Food Funct. 2014, 5, 74-84.

34. Bresciani, L.; Calani, L.; Bocchi, L.; Delucchi, F.; Savi, M.; Ray, S.; Brighenti, F.; Stilli, D.; Del Rio, D. Bioaccumulation of resveratrol metabolites in myocardial tissue is dose-time dependent and related to cardiac hemodynamics in diabetic rats. Nutr. Metab. Cardiovasc. Dis. 2014, 24, 408-415.

35. Sharan, S.; Iwuchukwu, O.F.; Canney, D.J.; Zimmerman, C.L.; Nagar, S. In vivo-formed versus preformed metabolite kinetics of trans-resveratrol-3-sulfate and trans-resveratrol-3-glucuronide. Drug Metab. Dispos. 2012, 40, 1993-2001.

36. Patel, K.R.; Andreadi, C.; Britton, R.G.; Horner-Glister, E.; Karmokar, A.; Sale, S.; Brown, V.A.; Brenner, D.E.; Singh, R.; Steward, W.P.; et al. Sulfate metabolites provide an intracellular pool for resveratrol generation and induce autophagy with senescence. Sci. Transl. Med. 2013, 5, 205 ra133.

37. Andreadi, C.; Britton, R.G.; Patel, K.R.; Brown, K. Resveratrol-sulfates provide an intracellular reservoir for generation of parent resveratrol, which induces autophagy in cancer cells. Autophagy 2014, 10, 524-525.

38. Subramanian, L.; Youssef, S.; Bhattacharya, S.; Kenealey, J.; Polans, A.S.; van Ginkel, P.R. Resveratrol: Challenges in translation to the clinic - a critical discussion. Clin. Cancer Res. 2010, $16,5942-5948$.

39. Moyano-Mendez, J.R.; Fabbrocini, G.; de Stefano, D.; Mazzella, C.; Mayol, L.; Scognamiglio, I.; Carnuccio, R.; Ayala, F.; la Rotonda, M.I.; de Rosa, G. Enhanced antioxidant effect of transresveratrol: Potential of binary systems with polyethylene glycol and cyclodextrin. Drug Dev. Ind. Pharm. 2014, 40, 1300-1307.

40. Ansari, K.A.; Vavia, P.R.; Trotta, F.; Cavalli, R. Cyclodextrin-based nanosponges for delivery of resveratrol: In vitro characterisation, stability, cytotoxicity and permeation study. AAPS PharmSciTech 2011, 12, 279-286.

41. Lee, M.H.; Kao, L.; Lin, C.C. Comparison of the antioxidant and transmembrane permeative activities of the different Polygonum cuspidatum extracts in phospholipid-based microemulsions. J. Agric. Food Chem. 2011, 59, 9135-9141. 
42. Sessa, M.; Tsao, R.; Liu, R.; Ferrari, G.; Donsi, F. Evaluation of the stability and antioxidant activity of nanoencapsulated resveratrol during in vitro digestion. J. Agric. Food Chem. 2011, 59, 12352-12360.

43. Hung, C.F.; Chen, J.K.; Liao, M.H.; Lo, H.M.; Fang, J.Y. Development and evaluation of emulsion-liposome blends for resveratrol delivery. J. Nanosci. Nanotechnol. 2006, 6, 2950-2958.

44. Kobierski, S.; Ofori-Kwakye, K.; Muller, R.H.; Keck, C.M. Resveratrol nanosuspensions: Interaction of preservatives with nanocrystal production. Pharmazie 2011, 66, 942-947.

45. Stammet, M.; Kwon, G.S.; Rao, D.A. Drug loading in Pluronic(R) micelles made by solvent casting and equilibrium methods using resveratrol as a model drug. J. Control. Release 2010, 148, e50-e51.

46. Lu, X.; Ji, C.; Xu, H.; Li, X.; Ding, H.; Ye, M.; Zhu, Z.; Ding, D.; Jiang, X.; Ding, X.; et al. Resveratrol-loaded polymeric micelles protect cells from Abeta-induced oxidative stress. Int. J. Pharm. 2009, 375, 89-96.

47. Kristl, J.; Teskac, K.; Caddeo, C.; Abramovic, Z.; Sentjurc, M. Improvements of cellular stress response on resveratrol in liposomes. Eur. J. Pharm. Biopharm. 2009, 73, 253-259.

48. Neves, A.R.; Lucio, M.; Martins, S.; Lima, J.L.; Reis, S. Novel resveratrol nanodelivery systems based on lipid nanoparticles to enhance its oral bioavailability. Int. J. Nanomedicine 2013, 8, 177-187.

49. Figueiro, F.; Bernardi, A.; Frozza, R.L.; Terroso, T.; Zanotto-Filho, A.; Jandrey, E.H.; Moreira, J.C.; Salbego, C.G.; Edelweiss, M.I.; Pohlmann, A.R.; et al. Resveratrol-loaded lipid-core nanocapsules treatment reduces in vitro and in vivo glioma growth. J. Biomed. Nanotechnol. 2013, 9, 516-526.

50. Cadena, P.G.; Pereira, M.A.; Cordeiro, R.B.; Cavalcanti, I.M.; Barros Neto, B.; Pimentel, M.C.C.B.; José Luiz Lima Filho; Silva, V.L.; Santos-Magalhaes, N.S. Nanoencapsulation of quercetin and resveratrol into elastic liposomes. Biochim. Biophys. Acta 2013, 1828, 309-316.

51. Sih, J.; Bansal, S.S.; Filippini, S.; Ferrati, S.; Raghuwansi, K.; Zabre, E.; Nicolov, E.; Fine, D.; Ferrari, M.; Palapattu, G.; et al. Characterization of nanochannel delivery membrane systems for the sustained release of resveratrol and atorvastatin: New perspectives on promoting heart health. Anal. Bioanal. Chem. 2013, 405, 1547-1557.

52. Shao, J.; Li, X.; Lu, X.; Jiang, C.; Hu, Y.; Li, Q.; You, Y.; Fu, Z. Enhanced growth inhibition effect of resveratrol incorporated into biodegradable nanoparticles against glioma cells is mediated by the induction of intracellular reactive oxygen species levels. Colloids Surf. B Biointerfaces 2009, 72, 40-47.

53. Frozza, R.L.; Bernardi, A.; Paese, K.; Hoppe, J.B.; da Silva, T.; Battastini, A.M.; Pohlmann, A.R.; Guterres, S.S.; Salbego, C. Characterization of trans-resveratrol-loaded lipid-core nanocapsules and tissue distribution studies in rats. J. Biomed. Nanotechnol. 2010, 6, 694-703.

54. Teskac, K.; Kristl, J. The evidence for solid lipid nanoparticles mediated cell uptake of resveratrol. Int. J. Pharm. 2010, 390, 61-69.

55. Gokce, E.H.; Korkmaz, E.; Dellera, E.; Sandri, G.; Bonferoni, M.C.; Ozer, O. Resveratrol-loaded solid lipid nanoparticles versus nanostructured lipid carriers: Evaluation of antioxidant potential for dermal applications. Int. J. Nanomedicine 2012, 7, 1841-1850.

56. Sanna, V.; Roggio, A.M.; Siliani, S.; Piccinini, M.; Marceddu, S.; Mariani, A.; Sechi, M. Development of novel cationic chitosan-and anionic alginate-coated poly(D,L-lactide-co- 
glycolide) nanoparticles for controlled release and light protection of resveratrol. Int. J. Nanomedicine 2012, 7, 5501-5516.

57. Lu, X.; Xu, H.; Sun, B.; Zhu, Z.; Zheng, D.; Li, X. Enhanced neuroprotective effects of resveratrol delivered by nanoparticles on hydrogen peroxide-induced oxidative stress in rat cortical cell culture. Mol. Pharm. 2013, 10, 2045-2053.

58. Lee, C.W.; Yen, F.L.; Huang, H.W.; Wu, T.H.; Ko, H.H.; Tzeng, W.S.; Lin, C.C. Resveratrol nanoparticle system improves dissolution properties and enhances the hepatoprotective effect of resveratrol through antioxidant and anti-inflammatory pathways. J. Agric. Food Chem. 2012, 60, 4662-4671.

59. Tsai, C.H.; Vivero-Escoto, J.L.; Slowing, II; Fang, I.J.; Trewyn, B.G.; Lin, V.S. Surfactantassisted controlled release of hydrophobic drugs using anionic surfactant templated mesoporous silica nanoparticles. Biomaterials 2011, 32, 6234-6244.

60. Bu, L.; Gan, L.C.; Guo, X.Q.; Chen, F.Z.; Song, Q.; Qi, Z.; Gou, X.J.; Hou, S.X.; Yao, Q. Transresveratrol loaded chitosan nanoparticles modified with biotin and avidin to target hepatic carcinoma. Int. J. Pharm. 2013, 452, 355-362.

61. Guo, L.; Peng, Y.; Yao, J.; Sui, L.; Gu, A.; Wang, J. Anticancer activity and molecular mechanism of resveratrol-bovine serum albumin nanoparticles on subcutaneously implanted human primary ovarian carcinoma cells in nude mice. Cancer Biother. Radiopharm. 2010, 25, 471-477.

62. Biasutto, L.; Zoratti, M. Prodrugs of quercetin and resveratrol: A strategy under development. Current drug metabolism 2014, 15, 77-95.

63. Biasutto, L.; Mattarei, A.; Sassi, N.; Azzolini, M.; Romio, M.; Paradisi, C.; Zoratti, M. Improving the efficacy of plant polyphenols. Anticancer Agents Med. Chem. 2014, doi: $10.2174 / 1871520614666140627150054$.

64. Nagamura, S.; Kanda, Y.; Kobayashi, E.; Gomi, K.; Saito, H. Synthesis and antitumor activity of duocarmycin derivatives. Chem. Pharm. Bull. (Tokyo) 1995, 43, 1530-1535.

65. Senter, P.D.; Beam, K.S.; Mixan, B.; Wahl, A.F. Identification and activities of human carboxylesterases for the activation of CPT-11, a clinically approved anticancer drug. Bioconjug. Chem. 2001, 12, 1074-1080.

66. Savolainen, J.; Leppanen, J.; Forsberg, M.; Taipale, H.; Nevalainen, T.; Huuskonen, J.; Gynther, J.; Mannisto, P.T.; Jarvinen, T. Synthesis and in vitro/in vivo evaluation of novel oral $N$-alkyl- and N,N-dialkyl-carbamate esters of entacapone. Life Sci. 2000, 67, 205-216.

67. Thorberg, S.O.; Berg, S.; Lundstrom, J.; Pettersson, B.; Wijkstrom, A.; Sanchez, D.; Lindberg, P.; Nilsson, J.L. Carbamate ester derivatives as potential prodrugs of the presynaptic dopamine autoreceptor agonist (-)-3-(3-hydroxyphenyl)-N-propylpiperidine. J. Med. Chem. 1987, 30, 2008-2012.

68. Gee, J.M.; DuPont, M.S.; Day, A.J.; Plumb, G.W.; Williamson, G.; Johnson, I.T. Intestinal transport of quercetin glycosides in rats involves both deglycosylation and interaction with the hexose transport pathway. J. Nutr. 2000, 130, 2765-2771.

69. Cermak, R.; Landgraf, S.; Wolffram, S. Quercetin glucosides inhibit glucose uptake into brushborder-membrane vesicles of porcine jejunum. Br. J. Nutr. 2004, 91, 849-855.

70. Harris, J.M.; Chess, R.B. Effect of pegylation on pharmaceuticals. Nat. Rev. Drug Discov. 2003, 2, 214-221. 
71. Veronese, F.M.; Pasut, G. PEGylation, successful approach to drug delivery. Drug Discov. Today 2005, 10, 1451-1458.

72. Veronese, F.M.; Mero, A. The impact of PEGylation on biological therapies. BioDrugs 2008, 22, 315-329.

73. Ryan, S.M.; Mantovani, G.; Wang, X.; Haddleton, D.M.; Brayden, D.J. Advances in PEGylation of important biotech molecules: Delivery aspects. Expert Opin. Drug Del. 2008, 5, 371-383.

74. Hamidi, M.; Azadi, A.; Rafiei, P. Pharmacokinetic consequences of pegylation. Drug Deliv. 2006, 13, 399-409.

75. Das, S.; Lin, H.S.; Ho, P.C.; Ng, K.Y. The impact of aqueous solubility and dose on the pharmacokinetic profiles of resveratrol. Pharm. Res. 2008, 25, 2593-2600.

76. Camont, L.; Cottart, C.H.; Rhayem, Y.; Nivet-Antoine, V.; Djelidi, R.; Collin, F.; Beaudeux, J.L.; Bonnefont-Rousselot, D. Simple spectrophotometric assessment of the trans-/cis-resveratrol ratio in aqueous solutions. Anal. Chim. Acta 2009, 634, 121-128.

77. Bertacche, V.; Lorenzi, N.; Nava, D.; Pini, E.; Sinico, C. Host-Guest interaction study of resveratrol with natural and modified cyclodextrins. J. Incl. Phenom. Macrocycl. Chem. 2006, 55, 279-287.

78. Mattarei, A.; Azzolini, M.; Carraro, M.; Sassi, N.; Zoratti, M.; Paradisi, C.; Biasutto, L. Acetal derivatives as prodrugs of resveratrol. Mol. Pharm. 2013, 10, 2781-2792.

79. Biasutto, L.; Marotta, E.; Mattarei, A.; Beltramello, S.; Caliceti, P.; Salmaso, S.; Bernkop-Schnurch, A.; Garbisa, S.; Zoratti, M.; Paradisi, C. Absorption and metabolism of resveratrol carboxyesters and methanesulfonate by explanted rat intestinal segments. Cell. Physiol. Biochem. 2009, 24, 557-566.

80. Gouyon, F.; Caillaud, L.; Carriere, V.; Klein, C.; Dalet, V.; Citadelle, D.; Kellett, G.L.; Thorens, B.; Leturque, A.; Brot-Laroche, E. Simple-sugar meals target GLUT2 at enterocyte apical membranes to improve sugar absorption: A study in GLUT2-null mice. J. Physiol. 2003, 552, 823-832.

81. Kellett, G.L.; Brot-Laroche, E. Apical GLUT2: A major pathway of intestinal sugar absorption. Diabetes 2005, 54, 3056-3062.

82. Helliwell, P.A.; Richardson, M.; Affleck, J.; Kellett, G.L. Stimulation of fructose transport across the intestinal brush-border membrane by PMA is mediated by GLUT2 and dynamically regulated by protein kinase C. Biochem. J. 2000, 350, 149-154.

83. Tamai, I. Oral drug delivery utilizing intestinal OATP transporters. Adv. Drug Deliv. Rev. 2012, 64, 508-514.

84. Tamai, I.; Nakanishi, T. OATP transporter-mediated drug absorption and interaction. Curr. Opin. Pharmacol. 2013, 13, 859-863.

85. Shitara, Y.; Maeda, K.; Ikejiri, K.; Yoshida, K.; Horie, T.; Sugiyama, Y. Clinical significance of organic anion transporting polypeptides (OATPs) in drug disposition: Their roles in hepatic clearance and intestinal absorption. Biopharm. Drug Dispos. 2013, 34, 45-78.

86. Riha, J.; Brenner, S.; Bohmdorfer, M.; Giessrigl, B.; Pignitter, M.; Schueller, K.; Thalhammer, T.; Stieger, B.; Somoza, V.; Szekeres, T.; et al. Resveratrol and its major sulfated conjugates are substrates of organic anion transporting polypeptides (OATPs): Impact on growth of ZR-75-1 breast cancer cells. Mol. Nutr. Food Res. 2014, 58, 1830-1842.

87. Pochini, L.; Scalise, M.; Galluccio, M.; Indiveri, C. OCTN cation transporters in health and disease: Role as drug targets and assay development. J. Biomol. Screen. 2013, 18, 851-867. 
88. Tamai, I. Pharmacological and pathophysiological roles of carnitine/organic cation transporters (OCTNs: SLC22A4, SLC22A5 and Slc22a21). Biopharm. Drug Dispos. 2013, 34, 29-44.

89. Vacondio, F.; Silva, C.; Mor, M.; Testa, B. Qualitative structure-metabolism relationships in the hydrolysis of carbamates. Drug Metab. Rev. 2010, 42, 551-589.

90. Biasutto, L.; Marotta, E.; Garbisa, S.; Zoratti, M.; Paradisi, C. Determination of quercetin and resveratrol in whole blood - implications for bioavailability studies. Molecules 2010, 15, 6570-6579.

Sample Availability: Samples of the compounds $\mathbf{2}$ and $\mathbf{3}$ are available from the authors.

(C) 2014 by the authors; licensee MDPI, Basel, Switzerland. This article is an open access article distributed under the terms and conditions of the Creative Commons Attribution license (http://creativecommons.org/licenses/by/4.0/). 